\title{
POLITIK HUKUM PENGAMPUNAN PAJAK DALAM PERSPEKTIF LAW AND DEVELOPMENT
}

\section{(THE POLITICAL LAW OF TAX AMNESTY IN THE PERPECTIVE OF LAW AND DEVELOPMENT)}

\author{
Oleh: Akmaluddin Rachim \\ Peneliti Hukum \\ Email: adinrach91@gmail.com
}

\begin{abstract}
ABSTRAK
Tujuan dari penelitian ini ada dua. Pertama, untuk mengetahui dan menganalisis politik hukum pengampunan pajak dalam perspektif Law and Development. Kedua, untuk mengetahui seharusnya politik hukum pengampunan pajak dalam perspektif Law and Development pada masa akan datang. Penelitian ini merupakan jenis penelitian hukum normatif-empiris. Cara dan alat pengumpulan data dilakukan dengan studi kepustakaan dan studi lapangan. Data yang terkumpul dianalisis menggunakan metode deskriptif kualitatif. Hasil dari penelitian ini ialah politik hukum pengampunan pajak kaitannya dengan perspektif Law and Development, masih belum optimal dengan meninjau hasil capaian kebijakan pengampunan pajak. Aspek parameter disiplin maupun mekanisme dampak peraturan, politik hukum pengampunan pajak cenderung mengesampingkan kaidah pembentukan peraturan perundang-undangan yang benar. Politik hukum pengampunan pajak jika dikaitkan dengan perspektif Law and Development pada masa akan datang seyogianya pemangku kebijakan melakukan perencanaan terlebih dahulu, menyusun desain kebijakan dengan baik, serta menyiapkan infrastruktur yang dibutuhkan. Oleh sebab itu, politik hukum pengamp unan pajak ke depannya harus memiliki desain peraturan yang komprehensif, antisipasi kebijakan yang sejalan dengan tujuan pembangunan, kemampuan kebijakan dalam beradaptasi terhadap kondisi sosial, politik, dan ekonomi, serta adanya aturan main kelembagaan yang baik sehingga memiliki tujuan prioritas yang akan dicapai.
\end{abstract}

Kata Kunci: Politik Hukum, Pengampunan Pajak, Law and Development.

\section{ABSTRACT}

The purpose of this study there are two. The first, to know and analyze the political law of tax amnesty in the perspective of law and development. The second, to know the political law of tax amnesty in the perspective of law and development in the future. This research is a normative-empirical legal research. The data has been collected and then analyzed using qualitative descriptive method. The result of this research is that the political law of tax amnesty in relation to law and development perspective is basically still not optimal. As for the political law of tax amnesty if associated with the perspective of law and development in the future is the policy stakeholders should first plan, develop the policy design well, prepare all the necessary infrastructure. Therefore, the political law of tax amnesty in the future must have a comprehensive regulatory design, policy anticipation in line with the objectives of development, the ability of the policy to adapt to all social, political and economic conditions, and the existence of good institutional rules, so have a purpose priority to be achieved.

Keywords: Political of Law, Tax Amnesty, Law and Development. 


\section{A. Pendahuluan}

Perkembangan pertumbuhan ekonomi Indonesia, sejak lima tahun terakhir mengalami perlambatan. Hal tersebut terlihat dari tren pertumbuhan ekonomi Indonesia sejak tahun 2011 hingga 2015. Tahun 2012 berada diangka 6,0\%. Tahun 2013 tercatat menurun pada angka 5,6\%. Berikutnya pada tahun 2014 diangka 5,0\%. Pada tahun 2015, pertumbuhan ekonomi hanya mencapai angka $4,8 \%{ }^{1}$

Kondisi tersebut merupakan "efek domino" dari kondisi pertumbuhan ekonomi dunia yang juga mengalami tren perlambatan. Efek dari perlambatan tersebut secara langsung mempengaruhi perekonomian di Indonesia. Untuk mengatasi perlambatan pertumbuhan ekonomi nasional, diperlukan suatu terobosan kebijakan guna menemukan sumber pertumbuhan ekonomi baru.

Di sisi yang lain saat bersamaan perkembangan penerimaan negara dari sektor pajak berada pada tren positif. Kenyataan tersebut menunjukkan bahwa penerimaan negara dari sektor pajak kini memegang peranan sangat penting dalam memberikan stimulus terhadap pertumbuhan ekonomi. Hal tersebut dapat ditunjukkan dalam tren penerimaan negara dari sektor pajak. Tahun 2011 penerimaan pajak berada pada angka 61,4\%, tahun 2012 tercatat 62,5\%, tahun 2013 tercatat sebesar 64,0\%, tahun 2014 tercatat sekitar 63,5\% dan tahun 2015 tercatat sebesar 70,3\%. ${ }^{2}$

Capaian tersebut menunjukkan jikalau penerimaan negara dari sektor pajak sangat memuaskan dan memberikan harapan peningkatan penerimaan pajak. Besarnya capaian penerimaan negara dari pajak dapat diasumsikan bahwa kebijakan khusus terhadap bidang perpajakan mampu mengatasi perlambatan pertumbuhan ekonomi dan sumber pembiayaan pembangunan. Argumentasi tersebut menjelaskan bahwa negara memerlukan dana dari sektor pajak guna mempercepat pertumbuhan ekonomi dan pembiayaan pembangunan.

Indonesia sebenarnya memiliki berbagai alternatif sumber pembiayaan, namun peran pajak saat ini dalam penerimaan negara lebih menonjol. Penerimaan negara dari sektor pajak dapat

1 Putusan Mahkamah Konstitusi Nomor 57/PUU-XIV/2016 perihal Pengujian Undang-Undang Nomor 11 Tahun 2016 tentang Pengampunan Pajak, "keterangan presiden atas materi undang-undang yang dimohonkan pengujian, hlm. 92.

2 Ibid. 
dikatakan sebagai primadona dalam pembiayaan pembangunan nasional. $^{3}$ Pentingnya pajak bagi sumber pembiayaan pembangunan, mendorong pemerintah semakin gencar mengeluarkan kebijakan guna meningkatkan penerimaan pajak.

Keinginan pemerintah tersebut juga dipengaruhi oleh kondisi penerimaan pajak di Indonesia yang sesungguhnya belum optimal jika dibandingkan dengan negaranegara tetangga lainnya. Tax ratio Indonesia pada tahun 2012 berada pada kisaran angka $11,9 \%$, sedangkan negaranegara seperti Malaysia pada kisaran 15,61\%, Singapura 13,85\%, Philipina, 12,89\%, dan Thailand 15,45\%. ${ }^{4}$ Adapun tax ratio negara-negara berkembang lainya seperti Korea Selatan berada pada angka 25\%, Afrika Selatan 27\% dan Brasil sekitar 34\%. Berkaca dari kondisi tersebut, pemerintah Indonesia tertantang untuk terus mendorong penerimaan negara dari sektor pajak.

Darussalam mengemukakan ada 4 hal yang ditengarai menyebabkan rendahnya tax ratio di Indonesia, antara lain: besarnya shadow economy, rendahnya kepatuhan pajak, struktur penerimaan pajak yang tidak berimbang, dan globalisasi dan kebocoran pajak. $^{5}$ Apa yang disampaikan oleh Darussalam tersebut, menegaskan kembali argumentasi sebelumnya, bahwa salah satu permasalahan utama pajak di Indonesia sesungguhya terpusat pada persoalan kepatuhan wajib pajak.

Kenyataan tersebut juga sekaligus menegaskan bahwa terdapat masalah dalam sistem perpajakan di Indonesia. Di satu sisi pemerintah berkeinginan meningkatkan penerimaan negara dari sektor pajak, sementara di sisi yang lain terdapat masalah besar, yaitu rendahnya kepatuhan wajib pajak, banyaknya wajib pajak yang belum melaporkan hartanya di dalam dan luar negeri, dan kewenangan Direktorat Jenderal Pajak (selanjutnya disingkat DJP) yang terbatas dalam mengakses data perbankan.

Terungkapnya skandal dokumen rahasia Mossack Fonseca atau lebih dikenal dengan istilah skandal Panama Papers, membuktikan masalah tersebut. Skandal

3 Wirawan B. Ilyas dan Richard Burton, 2010, Hukum Pajak, Salemba Empat, Jakarta, hlm. 10.

4 Putusan Mahkamah Konstitusi Nomor 57/PUU-XIV/2016 perihal Pengujian Undang-Undang Nomor 11 Tahun 2016 tentang Pengampunan Pajak, "keterangan presiden atas materi undang-undang yang dimohonkan pengujian, hlm. 97.

5 Ibid., hlm. 250. 
tersebut menyebutkan ada sekitar 1.038 wajib pajak yang berasal dari Indonesia. ${ }^{6}$ Menurut Bambang Brodjonegoro, diperkirakan uang dan aset warga negara Indonesia yang berada di luar negeri, lebih dari nilai produk domestik bruto Indonesia, atau sekitar 11 ribu triliun. ${ }^{7}$

Kebijakan pengampunan pajak pada akhirnya mendapatkan basis legitimasinya melalui Undang-Undang Nomor 11 Tahun 2016 Tentang Pengampunan Pajak (selanjutnya disingkat UU Pengampunan Pajak). Ketentuan konsideran UU Pengampunan Pajak, menjelaskan bahwa untuk meningkatkan penerimaan negara dan pertumbuhan perekonomian serta kesadaran dan kepatuhan masyarakat dalam pelaksanaan kewajiban perpajakan, maka perlu menerbitkan kebijakan pengampunan pajak.

Keberadaan kebijakan program pengampunan pajak diartikan sebagai instrumen perubahan sistem perpajakan agar lebih berkeadilan. Kebijakan pengampunan pajak juga dipergunakan untuk meningkatkan pertumbuhan ekonomi guna pembiayaan pembangunan. Konsteks dari tujuan tersebut dimaknai sebagai bagian tak terpisahkan dengan kajian Law and Development. Kajian Law and Development pada prinsipnya merupakan kajian yang berkosentrasi pada bagaimana hukum berperan terhadap pembangunan. Terkait dengan hukum dan pembangunan, menurut Mochtar KusumaAtmadja, mengatakan bahwa:

"peranan hukum dalam
pembangunan adalah untuk
menjamin bahwa perubahan itu
terjadi secara teratur (tertib).
Hukum berperan melalui bantuan
perundang-undangan dan
keputusan (pengadilan), atau
kombinasi dari keduanya; namun
pembentukan perundang-undangan
adalah cara yang paling rasional
dan cepat jika dibandingkan dengan
metode pengembangan hukum lain
seperti yurisprudensi dan hukum
kebiasaan".

Kebijakan pengampunan pajak dibutuhkan bukan hanya sebagai instrumen keadilan dan pemerataan, tetapi juga sebagai instrumen pembangunan regional. ${ }^{9}$

Ibid., hlm.179.

7 "Panama Papers, Jejak Korupsi Global dari Panama", https://investigasi.tempo.co/panama/, diakses 19 Juni 2017.

8 Shidarta, et al. 2012, Mochtar Kusuma-Atmadja dan Teori Hukum Pembangunan, Epistema Institue, Jakarta, hlm. 21.

9 Haula Rosdiana dan Edi Slamet Irianto, 2012, Pengantar Ilmu Pajak: Kebijakan dan Implementasi di Indonesia, Rajawali Pers, Jakarta, hlm. 49, 
Oleh sebab itu, UU Pengampunan Pajak dapat dipahami sebagai payung hukum yang menjadi pondasi dan memberikan pengaruh terhadap upaya pertumbuhan ekonomi dan pembangunan nasional. Dampak langsung dari diberlakukannya kebijakan program pengampunan pajak, antara lain dapat dilihat dari catatan berikut ini:

1. Penguatan nilai tukar rupiah dari $\mathrm{Rp}$ 13.335,00 pada tanggal 27 Juni 2016 (sebelum UU Pengampunan Pajak disahkan Dewan Perwakilan Rakyat) menjadi Rp. $13.110,00$ pada tanggal 20 Juli 2016 atau menguat Rp 225,00 $(1,69 \%)$, bahkan sempat menguat ke level 13.085,00 pada tanggal 14 Juli 2016; dan

2. Respon positif dari pasar obligasi dan obligasi dengan disahkannya UU Pengampunan Pajak. ${ }^{10}$

Catatan itu mengindikasikan adanya optimisme pasar dan kemungkinan keberhasilan dari diberlakukannya UU Pengampunan Pajak cukup tinggi. Pada perkembangannya, optimisme akan keberhasilan dari diberlakukannya kebijakan tersebut menjadi "perjudian" pemerintahan saat ini. Diketahui sebelumnya, bahwa kebijakan tersebut menuai banyak kritik dari berbagai kalangan dan prospek keberhasilan kebijakan program pengampunan pajak di berbagai negara terbilang sangat kecil. Menurut Direktur Eksekutif Center for Indonesia Taxation Analysis (selanjutnya disingkat CITA), Yustinus Prastowo, mengatakan ada empat indikator yang dapat digunakan untuk mengukur kinerja program pengampunan pajak. Indikator tersebut antara lain: deklarasi harta, repatriasi, uang tebusan dan partisipan. ${ }^{11}$ Berdasarkan indikator tersebut, capaian dari program pengampunan pajak dapat diketahui.

Berikut ini capaian-capaian dari program pengampunan pajak. Target dari deklarasi harta berjumlah Rp. 4.000 triliun. Adapun capaian dari deklarasi tersebut, terkumpul Rp. 4.866 triliun harta yang dideklarasikan, terdiri dari Rp. 3.687 triliun deklarasi dalam negeri dan Rp. 1.032 triliun deklarasi luar negeri. Angka tersebut menunjukkan bahwa capaian target dari

10 Putusan Mahkamah Konstitusi Nomor 57/PUU-XIV/2016 perihal Pengujian Undang-Undang Nomor 11 Tahun 2016 tentang Pengampunan Pajak, "keterangan presiden atas materi undang-undang yang dimohonkan pengujian, hlm. 128.

11 Yustinus Prastowo, Pasca-program Amnesti Pajak, Kompas, 5 April 2017. 
deklarasi harta terlampaui. Di sisi repatriasi, target dari repatriasi harta berjumlah $\mathrm{Rp}$. 1.000 triliun. Capaian dari target tersebut hanya terkumpul Rp. 147 triliun. Angka tersebut menunjukkan bahwa capaian target dari repatriasi harta tidak tercapai. Perihal uang tebusan, pemerintah menargetkan dapat mengumpulkan Rp. 165 triliun. Adapun capaian dari target tersebut, terkumpul Rp. 115 triliun atau berada dikisaran $82 \%$ dari target. Tingkat partisipasi wajib pajak juga sangat tinggi. Tercatat hampir satu juta wajib pajak, baik orang pribadi, badan, maupun UMKM. ${ }^{12}$

Berdasarkan empat indikator tersebut, Yustinus Prastowo menilai program pengampunan pajak berhasil diterapkan. ${ }^{13}$ Berbeda dengan Yustinus Prastowo, menurut Ahmad Heri Fidaus dari Institute for Development of Economics and Finance (selanjutnya disingkat INDEF), mengatakan bahwa pemerintah justru gagal dalam menjalankan kebijakan program pengampunan pajak. Hal tersebut terlihat dari tidak seimbangnya perolehan dengan target yang disusun pemerintah. Indikasi tersebut dapat ditunjukkan, misalnya dari Rp. 11 ribu triliun aset yang berada di luar negeri, hanya Rp. 1.183 triliun yang terungkap. Pencapaian repatriasi Rp. 147 triliun yang jauh dari target sebesar 1.000 triliun. Deklarasi aset dalam negeri senilai Rp 3.694 triliun, menunjukkan betapa lemahnya kerja aparat perpajakan selama ini. ${ }^{14}$

Terlepas dari dua pendapat yang berbeda tersebut dalam menilai apakah program tax amnesty berhasil atau tidak pemerintah tetap berhak mengklaim bahwa program pengampunan pajak di Indonesia berhasil diwujudkan dan sebagai salah satu yang tersukses di dunia. Terlihat dari dana tebusan yang dikantongi pemerintah lebih besar dibandingkan dengan yang diperoleh dari negara-negara yang pernah menggelar program serupa. Klaim tersebut lantas ditanggapi oleh beberapa lembaga yang justru memberikan penilaian sebaliknya.

Indikasinya adalah harta yang bisa dipulangkan dari luar negeri tidak mencapai $20 \%$ dari target semula, padahal salah satu

12 Majalah Gatra, Skenario Lanjutan Pasca Program Pengampun Pajak Berakhir, Edisi 6-12 April 2017, hlm. 26. Lihat juga Majalah Tempo, Melempem Di Babak Akhir, Edisi 10-16 April 2017, hlm. 88-90.

13 Yustinus Prastowo, 2017, Pengampu(n)an Pajak Historiografi Perjalanan Amnesti Pajak di Indonesia, CITA Riset Fiskal, Jakarta. hlm. 233.

14 Majalah Tempo, Edisi 10-16 April 2017, hlm. 87. 
tujuan utamanya menarik kembali harta yang disembunyikan. ${ }^{15}$ Berdasarkan atas uraian sebelumnya, terlihat adanya masalah perbedaan pandangan dalam memberikan penilaian atas capaian hasil dari kebijakan pengampunan pajak.

Berpijak dari hal itu, untuk menengahi perbedaan pandangan tersebut, kebijakan pengampunan pajak perlu dikaji kembali dengan menggunakan perspektif Law and Development. Kebijakan pengampunan pajak sejatinya merupakan kebijakan yang secara teori berpijak dari salah satu fungsi utama pajak, yaitu fungsi mengatur. Pada prinsipnya, pajak memiliki banyak fungsi. Pajak memiliki fungsi anggaran, fungsi mengatur, fungsi alokasi, fungsi distribusi, dan fungsi stabilitas. Pajak juga berfungsi sebagai instrumen kebijakan pembangunan. ${ }^{16}$ Oleh sebab itu, kebijakan pengampunan pajak kemudian dikaji dari perspektif Law and Development.

Berdasarkan uraian tersebut, penulis lantas mengkaji keberadaan UU Pengampunan Pajak dari perspektif Law and Development. Keberadaan UU Pengampunan Pajak dengan pelbagai capaiannya tersebut, senantiasa perlu dilakukan kajian lebih lanjut. Kajian ini dilakukan guna menemukan jawaban akademik yang dapat menjelaskan capaian dari pelaksanaan kebijakan program pengampunan pajak. Oleh sebab itu, atas dasar pemaparan dan uraian sebelumnya, penulis melakukan penelitian tesis dengan judul "Politik Hukum Pengampunan Pajak dalam Perspektif Law and Development" selanjutnya bagaimana seharusnya politik hukum pengampunan pajak jika dikaitkan dengan perspektif Law and Development pada masa akan datang.

\section{B. Metode Penelitian}

Penelitian hukum merupakan kegiatan ilmiah, yang didasarkan pada metode, sistematika dan pemikiran, bertujuan untuk mempelajari suatu atau beberapa gejala hukum dengan jalan menganalisisnya. ${ }^{17}$ Penelitian hukum pada dasarnya suatu proses menemukan aturan hukum, prinsip-prinsip hukum, maupun doktrin-doktrin hukum guna menjawab isu hukum yang dihadapi masyarakat. ${ }^{18}$

5 Ibid., hlm. 88.

6 Haula Rosdiana dan Edi Slamet Irianto, Op.cit., hlm. 48.

7 Soerjono Soekanto, 1984, Pengantar Penelitian Hukum, UI Press, Jakarta, hlm. 43.

18 Peter Mahmud Marzuki, 2010, Penelitian Hukum, Kencana, Jakarta, hlm. 35. 
Penelitian ini merupakan penelitian hukum normatif empiris.

Cara pengumpulan data dalam penelitian hukum normatif empiris ini, dilakukan dengan menggunakan teknik studi kepustakaan dan studi lapangan.

a) Pengumpulan data sekunder dilakukan dengan cara studi kepustakaan. Pengumpulan data dilakukan dengan cara menginventarisasi berbagai peraturan perundang-undangan, putusan pengadilan, dokumen hukum, laporan hukum, maupun catatan hukum lainnya.

b) Pengumpulan data primer dilakukan dengan wawancara. Metode wawancara dilakukan berdasarkan pedoman wawancara yang telah disusun oleh peneliti. Untuk memperkuat wawancara, peneliti juga mengumpulkan bahan-bahan hukum yang terkait dengan topik penelitian.

Berdasarkan sifat penelitian yang digunakan, yaitu menggunakan metode penelitian bersifat deskriptif analisis. Analisis data menggunakan pendekatan kualitatif terhadap data primer dan sekunder. Oleh sebab itu, analisis data dalam penelitian hukum normatif empiris ini menggunakan metode analisis deskriptif-kualitatif.

Lokasi penelitian data sekunder berada di Provinsi Daerah Istimewa Yogyakarta. Penelitian dilakukan di Universitas Gadjah Mada. Lokasi penelitian data primer di Provinsi Daerah Khusus Ibukota Jakarta. Penelitian dilakukan di Direktorat Jenderal Pajak, Dewan Perwakilan Rakyat Republik Indonesia serta di Center for Indonesia Taxation Analysis (CITA), dan Institute for Development of Economics and Finance (INDEF).

\section{Pembahasan}

1. Politik Hukum Pengampunan Pajak Jika Dikaitkan dengan Perspektif Law and Development

Jika ditinjau dari perspektif Law and Development, maka uraian politik hukum pengampunan pajak harus didasarkan parameter yang mendasarinya. Pertama, parameter disiplin dari Teori Law and Development mengindikasikan bahwa politik hukum pengampunan pajak dikeluarkan sebagai bagian upaya pemerintah dalam meningkatkan penerimaan pajak guna mendorong akselarasi 
pembangunan demi kesejahteraan masyarakat. Program pengampunan pajak adalah kebijakan pemerintah yang telah mendapatkan persetujuan legislatif dan dinyatakan tidak bertentangan dengan konstitusi melalui putusan Mahkamah Konstitusi Nomor 57/PUU-XIV/2016 perihal Pengujian Undang-Undang Nomor 11 Tahun 2016 tentang Pengampunan Pajak. Legitimasi tersebut menandakan bahwa kebijakan tax amnesty memiliki manfaat yang sangat besar.

Politik hukum pengampunan pajak 2016 memiliki payung hukum yang kuat karena didasarkan pada ketentuan undang-undang, yang khusus membahas perihal pengampunan pajak. Hal ini berbeda dengan politik hukum pengampunan pajak sebelumnya, yang hanya didasarkan pada Kepres, Perpres, dan UU yang tidak secara khusus mengaturnya. Adapun berbagai peraturan turunan seperti: Peraturan Menteri Keuangan, Keputusan Menteri Keuangan dan Peraturan Dirjen Pajak menjadi bukti bahwa secara hukum,
UU Pengampunan Pajak Tahun 2016 didukung oleh berbagai peraturan pelaksana yang memadai.

Keberadaan kebijakan pengampunan pajak pada prinsipnya telah mengakomodasi sejumlah ketentuan yang dianut dalam undang-undang $a$ quo, walaupun masih "setengah hati". Pada aspek desain peraturan dari parameter mekanisme dampak peraturan dalam Teori Law and Development, salah satunya mengharuskan suatu kebijakan yang terbentuk mengakomodasi ketentuan yang ada dalam prinsip regulatory impact assessment. ${ }^{19}$ Ketentuan tersebut merupakan salah satu alat atau pendekatan yang dapat digunakan untuk meningkatkan kualitas kebijakan pemerintah. Pembentukan kebijakan pengampunan pajak pada dasarnya belum menggunakan prinsip yang dianut dalam paradigma regulatory impact assessment. Hal tersebut terlihat dari ketidakjelasan orientasi tujuan yang akan dicapai dari kebijakan pengampunan pajak, partisipasi publik dalam pembentukan kebijakan tidak

19 Yong Shik Lee, General Theory of Law and Development, Cornell International Law Journal, Vol. 50. No. 3 Desember 2017, United Stated, hlm. 23. 
dilibatkan di setiap prosesnya dan berbagai aspek lainnya.

$\begin{array}{ccc}\text { Aspek kepatuhan terhadap } & \\ \text { peraturan, kepatuhan terhadap }\end{array}$ kebijakan program pengampunan pajak dapat dilihat dari partisipasi masyarakat dalam mengikuti program tersebut. Menurut informasi yang ada, kepatuhan wajib pajak, baik orang pribadi, badan maupun UMKM terhadap program pengampunan pajak diikuti hampir satu juta (965.983) wajib pajak. Hasil tersebut terbilang belum memuaskan jika dibandingkan dari target yang ingin dicapai sekitar dua juta wajib pajak. Target yang sebenarnya sangat rendah jika dibandingkan dengan data wajib pajak yang berjumlah 32.769 .215 pada tahun 2016. Jomplangnya tingkat partisipasi wajib pajak yang terdata dengan yang mengikuti program, sesungguhnya menyisakan suatu permasalahan yang sebenarnya belum teratasi. Salah satu tujuan penting dari program pengampunan pajak adalah untuk meningkatkan basis data wajib pajak.
Jika melihat kenyataan tersebut, maka hasilnya tentu belum optimal.

Menurut hasil kajian dari INDEF yang menyatakan bahwa minimnya partisipasi dari wajib pajak akan memberikan dampak kurang baik bagi peningkatan basis data wajib pajak ke depannya. Hasil kajian INDEF juga menyatakan bahwa secara keseluruhan daya tarik kebijakan program pengampunan pajak hanya mampu menggaet 50.385 wajib pajak baru. Itu artinya bahwa hanya 0,15\% dari wajib pajak potensial yang berpartisipasi. Rendahnya kepatuhan wajib pajak dalam berpartisipasi dalam program pengampunan pajak menandakan bahwa kehadiran presiden dalam beberapa sosialisasi tak mampu meyakinkan publik akan manfaat yang diperoleh.

Saka Winih mengatakan bahwa variabel sosialisasi tidak memiliki pengaruh terhadap efektivitas keberhasilan kebijakan program pengampunan pajak. ${ }^{20}$ Apalagi jika polemik perihal keadilan tidak

20 Saka Winih W, 2016, Analisis Faktor yang Mempengaruhi Efektivitas Kebijakan Pengampunan Pajak, Program Studi Sarjana Akuntansi Fakultas Ekonomika dan Bisnis Universitas Gadjah Mada, Skripsi, Yogyakarta, hlm. 73. 
dikemukakan dengan baik saat sosialisasi, maka publik tentu masih menyisakan praduga. Padahal sesunguhnya variabel keadilan sangat berpengaruh terhadap efektivitas kebijakan pengampunan pajak. ${ }^{21}$ Berdasarkan hasil penelitian, wajib pajak masih banyak yang belum mematuhi program pengampunan pajak, yang sebenarnya merupakan program one shot oppurtunity. Pemaparan tersebut menunjukkan bahwa sesungguhnya tingkat partisipasi dan kepatuhan wajib pajak terhadap kebijakan program pengampunan pajak masih sangat rendah. Faktor yang menyebabkan rendahnya partisipasi wajib pajak dapat berupa tidak efektifnya sosialisasi yang dilakukan pemerintah dan masyarakat belum mampu menginternalisasinya ataupun telah hilangnya trust dari wajib pajak kepada aparat pajak. Jikalau faktor yang terakhir tersebut lebih dominan mempengaruh tingkat partisipasi, maka hal tersebut sungguh menjadi "tamparan keras" buat pemerintah.
Terkait dengan faktor sosialisasi, penelitian yang dilakukan oleh Saka Winih penting untuk analisis. Saka Winih sebelumnya mengatakan bahwa sebenarnya variabel sosialisasi tidak memiliki pengaruh terhadap efektivitas kebijakan pengampunan pajak. Padahal menurut Saka Winih mengutip pendapat dari James Alm. dan William yang mengatakan bahwa sosialisasi berpengaruh terhadap keberhasilan program tax amnesty. ${ }^{22}$ Suatu hal yang paradoks. Maksud dari variabel sosialisasi tidak berpengaruh terhadap efektivitas, jika hal tersebut dilakukan tanpa parameter keberhasilan. Adanya parameter keberhasilan akan memberikan data yang penting untuk menyusun proyeksi sosialisai yang lebih efektif ke depannya. Saka Winih selanjutnya mengatakan bahwa variabel pengetahuan sebenarnya banyak memberikan pengaruh terhadap efektivitas kebijakan pengampunan pajak. Hal tersebut didasarkan pada penelitian sebelumnya dilakukan oleh Loo, Mckerchar dan Hansford, yang 
menyatakan bahwa pengetahuan yang dimiliki wajib pajak berpengaruh positif terhadap tingkat kepatuhan membayar pajak. ${ }^{23}$

Aspek kualitas pelaksanaan dari kebijakan pengampunan pajak dapat ditinjau dari aspek kemampuan negara dan kemauan politik. Secara umum, kualitas pelaksanaan program pengampunan pajak terbilang memuaskan. Hal tersebut dibuktikan dengan angka-angka capaian realisasi program pengampunan pajak. Target dari deklarasi harta berjumlah $\mathrm{Rp}$. 4.000 triliun. Adapun capaian dari deklarasi tersebut, terkumpul Rp. 4.884 triliun harta yang dideklarasikan, terdiri dari Rp. 3.701 triliun deklarasi dalam negeri dan Rp. 1.037 triliun deklarasi luar negeri.

Angka tersebut menunjukkan bahwa capaian target dari deklarasi harta terlampaui. Di sisi repatriasi, target dari repatriasi harta berjumlah Rp. 1.000 triliun. Capaian dari target tersebut hanya terkumpul Rp. 147 triliun. Angka tersebut menunjukkan bahwa capaian target dari repatriasi harta tidak tercapai. Perihal uang tebusan, pemerintah menargetkan dapat mengumpulkan Rp. 165 triliun. Adapun capaian dari terget tersebut, terkumpul 115 triliun. Tingkat partisipasi wajib pajak terbilang tinggi, jika dibandingkan dengan target dua juta wajib pajak. Tercatat hampir satu juta (965.983) wajib pajak, baik orang pribadi, badan, maupun UMKM.

Hal yang kurang menggembirakan dari pada pelaksanaan kebijakan program pengampunan pajak adalah target utama yaitu repatriasi harta justru tidak optimal. Dari 1000 triliun yang ditargetkan, hanya sekitar Rp 147 triliun yang terealisasi. Padahal Yustinus Prastowo mengatakan bahwa capain repatriasi adalah parameter yang sangat menentukan keberhasilan program tax amnesty. ${ }^{24} \mathrm{Hal}$ tersebut tentunya didasarkan pada keinginan presiden yang sangat mengutamakan repatriasi.

Capaian tersebut terbilang sangat tidak memuaskan. Capaian tersebut sekaligus menunjukkan bahwa kemampuan negara dalam menarik

23 Ibid.

24 Yustinus Prastowo, Op.cit., Pengampu(n)an Pajak Historiografi... hlm. 84. 
kembali aset warga negara yang terparkir di luar negeri belum berhasil dilakukan. Data deklarasi harta dalam negeri, hanya mencapai sebesar Rp 3.701 triliun, sedangkan dari Rp 11 ribu triliun potensi aset yang diduga berada di luar negeri, hanya Rp 1.183 triliun yang terungkap. Kenyataan tersebut menunjukkan betapa lemahnya kerja aparat perpajakan dalam mengungkap potensi pajak dalam negeri dan memulangkan potensi aset yang terparkir di luar negeri. Tingkat partisipasi atau kepatuhan wajib pajak dalam mengikuti program pengampunan pajak juga menunjukkan angka yang belum memuaskan.

Terkait dengan aspek kualitas pelaksanaan dari pendekatan kemampuan negara, pelaksanaan kebijakan program pengampunan pajak terindikasi negara belum memiliki kemampuan yang cukup kuat menghadapi berbagai tantangan, baik yang datang dari dalam negeri maupun dari luar negeri. Tantangan yang datang dari dalam negeri adalah yang rendahnya partisipasi wajib pajak dan perilaku korup aparatur pajak. Khusus perilaku korup aparatur pajak, tata laku tersebut sangat menciderai, menodai dan bahkan dapat "menista" kelangsungan kepercayaan wajib pajak terhadap aparatur pajak. Kenyataan tersebut pada akhirnya mengganggu kinerja realisasi penerimaan pajak.

Tantangan yang datang dari luar adalah upaya Singapura yang mencoba mengganggu pelaksanaan program pengampunan pajak. Singapura dikabarkan mencoba menahan agar uang tersebut tidak kembali ke Indonesia dengan mengiming-iming kewarganegaraan, status permanent resident, proteksi dana lewat private bank hingga berani menalangi tebusan asalkan nasabah tak membawa pulang uang ke Indonesia. ${ }^{25}$ Singapura juga berlindung di balik keikutsertaan di FATF, di mana Singapura berusaha mempersulit para warga negara Indonesia untuk mengikut tax amnesty melalui repatriasi. ${ }^{26}$ Tantangan tersebut sesungguhnya sangat berat dan kecenderungannya Indonesia tak mampu menghadapinya.

25 Majalah Tempo, Edisi 25-31 Juli 2016.

26 Yustinus Prastowo, Op.cit., hlm. 108. 
Aspek lain dari kualitas pelaksanaan adalah kemauan politik. Pelaksanaan kebijakan program pengampunan pajak dari pendekatan politik dapat dikatakan sangat kuat. Presiden sangat berkepentingan dengan program tersebut. Hal tersebut ditunjukkan dengan keikutsertaan presiden dalam sosialisasi ke berbagai daerah. Turut serta dan turun tangannya presiden dalam menyukseskan program pengampunan pajak dapat dipahami sebagai bagian dari upaya mengajak sebanyak-banyaknya partisipasi wajib pajak.

Kekurangan dari politik hukum pengampunan pajak jika ditinjau dari parameter disiplin (khususnya pada aspek kerangka hukum dan lembaga) Teori Law and Development adalah pada aspek berbagai peraturan pelaksanaannya, tidak memiliki aturan perihal mekanisme pengawasan dan penegakan hukum secara kelembagaan. Perkara suap aparat pajak, Handang Soekarno, ${ }^{27}$ adalah salah satu bukti nyata dari lemahnya profesionalitas aparat pajak dan ketidakmampuan atau ketidakberadaan sistem untuk membangun disiplin aparat pajak. Tindakan tersebut mencerminkan suatu pengkhianatan terhadap prinsip dan tata kelola yang baik, serta efektivitas dan kejujuran yang selama ini dianut oleh instansi terkait. ${ }^{28}$

Ditinjau dari mekanisme dampak peraturan. Aspek desain peraturan kebijakan pengampunan pajak belum mengakomodasi prinsip regulatory impact assessment. Pada aspek kepatuhan terhadap peraturan, pemerintah belum berhasil menggaet wajib pajak untuk berpartisipasi sepenuhnya dalam kebijakan program pengampunan pajak. Aspek terakhir dari mekanisme dampak peraturan adalah terkait dengan kualitas pelaksanaan. Hasil penelitian menunjukkan bahwa pada aspek tersebut, terkait dengan kemampuan negara dalam menghadapi tantangan yang datang dari luar. Indonesia terlihat lemah menghadapi Singapura

27 http://www.hukumonline.com/berita/baca/lt58343e35f2fc3/pejabat-pajak-tersangka-suap-rp1-9m-saat-pemerintah-gencarkan-tax-amnesty, diakses 16 Februari 2018

28 Ibid. 
yang melakukan upaya untuk

berubah menjadi isu pengampunan menggagalkan kebijakan pengampunan pajak.

Atas dasar pandangan tersebut, sesungguhnya mengonfirmasi bahwa kebijakan pengampunan pajak terlahir dalam keadaan prematur. Keadaan tersebut kemudian menunjukkan adanya suatu problem ketidakjelasan orientasi tujuan dan prioritas capaian yang selama ini akan dicapai. Kenyataan tersebut menunjukkan bahwa pelaksanaan kebijakan program pengampunan pajak tidak terarah atau tanpa prioritas sehingga hasilnya belum optimal.

2. Politik Hukum Pengampunan Pajak Jika Dikaitkan dengan Perspektif Law and Development pada Masa Akan

\section{Datang}

Berdasarkan data yang diperoleh saat proses pembahasan pembentukan UU Pengampunan Pajak, menunjukkan ada beberapa kali pergeseran orientasi tujuan yang akan dicapai. Misalnya ide awalnya adalah repatriasi, juga sempat

nasional, kemudian berubah ke arah isu perluasan basis pajak atau peningkatan penerimaan pajak. Hal tersebut sesungguhnya sangat membingungkan dan mengganggu tahapan pelaksanaan. Ketidakjelasan orientasi tujuan menyebabkan fokus perhatian menjadi tidak terarah dan hasilnya tidak akan optimal. Temuan penting dari adanya pergeseran orientasi tujuan atau basis filosofi yang kemudian menentukan arah politik hukum pengampunan pajak adalah adanya faktor pergantian pejabat di lingkungan Direktorat Jenderal Pajak. ${ }^{29}$ Pergantian tersebut menyebabkan terjadinya perubahan dasar filosofi kebijakan pengampunan pajak. Pada akhirnya kebijakan tersebut terlaksana atas dasar filosofi peningkatan penerimaan pajak dan peningkatan kesadaran wajib pajak, bukan atas dasar repatriasi seperti semula yang digagas. Kenyataan tersebut sekaligus menunjukkan ketidakmampuan dalam menerjemahkan keinginan presiden.

29 Menurut Andreas Eddy Susetyo, mulanya kebijakan a quo basis filosofisnya berbicara terkait dengan repatriasi ketika Direktorat Jenderal Pajak masih dipimpin oleh Sigit Priadi Pramudito. Lihat dalam Risalah Sidang Rapat Kerja Komisi XI DPR RI, Mendapatkan Masukan terkait Pembahasan RUU tentang Pengampunan Pajak, Rabu, 20 April 2016, hlm. 27. 
Desain politik hukum pengampunan pajak - dalam perspektif Law and Development - ke depannya mesti memperhatikan beberapa hal yang menjadi prasyarat perwujudannya. Pentingnya perspektif Law and Development digunakan dalam kebijakan pengampunan pajak agar kebijakan tersebut terarah dan memiliki skala prioritas tujuan yang akan dicapai. Parameter tersebut diharapkan dapat mengoptimalkan capaian keberhasilan program pengampunan pajak. Adapun uraian dari parameter Law and Development agar menjadi rujukan kebijakan pengampunan pajak ke depannya antara lain:

\section{Parameter Disiplin}

Parameter disiplin dari Teori Law and Development dalam politik hukum pengampunan pajak ke depannya, mesti terdiri dari beberapa prasyarat utama. Parameter tersebutlah yang nantinya sangat menentukan keberhasilan dari suatu kebijakan, program pengampunan pajak.
Uraian dari beberapa prasyarat tersebut akan dipaparkan di bawah ini.

\section{a. Hukum}

Prasyarat hukum yang dimaksudkan dalam teori tersebut adalah its generic sense as a body of rules of action or conduct prescribed by controlling authority, and having binding legal force or a specific rule or a set of rules binding on the members of a society. ${ }^{30}$ Suatu kebijakan mesti dikeluarkan oleh lembaga atau otoritas yang berwenang. Dalam konteks keIndonesian, otoritas pembuat kebijakan berasal dari lembaga eksekutif dan legislatif. Hal tersebut tegas diatur dalam UUD NRI 1945. Pasal 5 UUD NRI 1945 memberikan mandat kepada presiden dalam membentuk undang-undang dan peraturan pemerintah dalam menjalankan undang-undang sebagaimana mestinya. ${ }^{31}$ Pasal 20 UUD NRI

30 Yong Shik Lee, Op.cit., hlm. 10.

31 Pasal 5 UUD NRI 1945 menyatakan bahwa: 
1945 juga memberikan mandat kepada DPR dalam membentuk undang-undang. 32

Prasyarat pertama dari parameter disiplin teori ini secara tidak langsung menyatakan bahwa suatu politik hukum pengampunan pajak ke depannya, kebijakan yang dikeluarkan harus merupakan hasil pembahasan sempurna dari kedua lembaga negara. Hal tersebut guna memastikan bahwa kebijakan yang dibuat merupakan kebijakan yang mendapat dukungan penuh dari kedua lembaga tersebut. Jika dibutuhkan, keterlibatan yudikatif (Mahkamah Konstitusi atau Mahkmah Agung) untuk memastikan konstitusional atau legalitas suatu produk hukum, sehingga kekuatan hukumnya akan lebih yang mengikat. Ironisnya, jika mengharuskan atau terlibatnya yudikatif dalam menentukan suatu kebijakan agar lebih mengikat, berarti sejatinya kebijakan tersebut menunjukkan ketidaksempurnaan dalam proses pembuatannya atau karena masih menyisakan suatu problem.

Implikasinya jika sebuah politik hukum mendapat persetujuan bersama akan menghasilkan suatu kebijakan nasional yang demokratis dan berkarakter populis di masyarakat. Jika sebaliknya, kebijakan nasional dapat bersifat otoriter. Oleh sebab itu, prasyarat pertama ini menjadi sangat penting bagi keberlangsungan suatu kebijakan. Politik hukum pengampunan pajak ke depannya, apakah itu berasal dari lembaga eksekutif ataupun legislatif, mesti satu sama lain harus saling mendukung.

1. Presiden berhak mengajukan rancangan Undang-undang kepada Dewan Perwakilan Rakyat.

2. Presiden menetapkan Peraturan Pemerintah untuk menjalankan Undang-undang sebagaimana mestinya.

32 Pasal 20 ayat (1) UUD NRI 1945 menyatakan bahwa Dewan Perwakilan Rakyat memegang kekuasaan membentuk undang-undang 


\section{b. Kerangka Hukum}

Prasyarat kerangka hukum yang dimaksudkan di sini ialah refers to frameworks in which law is organized, including regulatory structures and legal systems. Legal frameworks are a determinant of regulatory impact. $^{33} \quad$ Prasyarat ini mengharuskan sebuah kebijakan atau politik hukum pengampunan pajak dapat bekerja efektif jika memiliki sistem hukum yang kuat, mencakup mekanisme pengawasan dan penegakan. Adanya sistem hukum yang kuat, menjadikan suatu kebijkan memiliki kerangka atau dasar pijakan sehingga tujuan yang akan dicapai dapat optimal. Sistem tersebut mengharuskan adanya aturan pelaksana yang menjabarkan cakupan dari kebijakan tersebut.

Program pengampunan pajak dapat berhasil jika telah tersedia komponen regulatory structures and legal systems yang prima. Lawrence $M$ Friedman telah mengingatkan sebelumnya bahwa efektivitas berkerjanya suatu hukum jika memiliki komponen sistem, struktur dan budaya hukum. Oleh sebab itu, ke depannya program pengampunan pajak, yang saat ini didasarkan pada payung hukum undang-undang, juga mesti dilengkapi dan diperhatikan secara serius terkait aturan pelaksanaannya. Aturan pelaksana harus seiring sejalan dengan aturan primernya. Tujuannya agar tidak menimbulkan kesimpangsiuran di masyarakat.

\section{c. Lembaga}

Prasyarat lembaga yang dimaksud dalam parameter disiplin Law and Development ini adalah refers to organizations, norms, and practices related to the adoption, implementation, and enforcement of law. The

33 Yong Shik Lee, Op.cit. hlm. 11. 
impact of law cannot be assessed separately from relevant institutions. ${ }^{34}$ Prasyarat ini menganjurkan bahwa keberhasilan kebijakan program pengampunan pajak mesti didukung oleh integritas kelembagaan yang kuat. Hal tersebut guna mengoptimalkan program dari suatu kebijakan. Misalnya, dalam hal ini adalah Direktorat Jenderal Pajak dan beberapa Bank yang ambil bagian dalam program tersebut. Keberhasilan ditentukan atau hanya akan tercipta jika kelembagaan tersebut memiliki wibawa dan kepercayaan dari masyarakat. Kepercayaan masyarakat hanya akan ada jika suatu institusi memiliki kewibawaan secara organisatoris dan independensi etis dari aparaturnya.

Kedua prasyarat tersebut dapat menjadi rujukan dalam menyukseskan dan mengoptimal -kan suatu kebijakan dari aspek kelembagaan. Faktor institusi dengan prasyarat tersebut hanya akan terlembaga dan terinternalisasi jika didasarkan pada aturan main kelembagaan. Aturan main tersebutlah yang nantinya menjadi dasar pedoman dari pola ucap dan pola laku suatu aparat, sehingga menciptakan kembali rasa saling percaya antara wajib pajak dan aparat pajak. Aturan main tersebut juga mengatur terkait dengan mekanisme pengawasan dan penegakan hukum dari suatu visi kelembagaan.

\section{Mekanisme Dampak Peraturan}

Bagian kedua dari parameter Law and Development ialah mekanisme dampak peraturan. Bagian ini menjelaskan hubungan sebab akibat antara hukum dan pembangunan. Suatu mekanisme di mana hukum mempengaruhi proses pembangunan, sehingga perubahan yang diinginkan terjadi secara teratur dan tertib. 


\section{a. Desain Peraturan}

Terkait dengan mekanisme dampak peraturan dalam Teori Law and Development, aspek desain peraturan akan menjadi sangat penting. Sifatnya yang fundamen dalam sebuah kebijkan, mengharuskan agar desain peraturan telah teruji sebelum diterapkan. Teruji sebelum diterapkan bermakna bahwa peraturan tersebut mesti telah melewati tahap atau prosedur yang diatur dalam UU Nomor 12 Tahun 2011 Tentang Pembentukan Peraturan Perundang-undangan.

Politik hukum pengampunan pajak ke depannya mesti di desain dengan sebaik mungkin berdasarkan prosedur yang telah ditentukan. Prasyarat pertama yang dianjurkan dari aspek desain peraturan dalam Teori Law and Development adalah adanya antisipasi terhadap hasil kebijakan. Antisipasi terhadap hasil kebijakan dilakukan dengan menggunakan parameter Regulatory Impact Assassment
(RIA). Prasyarat kedua yang dianjurkan dalam aspek peraturan adalah adanya sinergitas antara kerangka hukum dan lembaga hukum. Pada prasyarat ini menekankan bahwa agar tercipta efektivitas hukum, telah diuraikan sebelumnya bahwa suatu kebijakan perlu memiliki aturan pelaksana, agar menjadikannya mudah diimplementasikan.

Selain aturan pelaksana, juga perlu memiliki mekanisme pengawasan dan penegakan hukum, seperti kelembagaan khusus yang memiliki fungsi pengawasan dan penegakan hukum. Alhasil dengan demikian maka kebijakan tersebut memiliki infrastruktur hukum yang kuat dan komprehensif. Prasyarat ketiga yang mesti dimiliki oleh aspek desain peraturan adalah instrumen atau mekanisme adaptasi yang dapat mengindentifikasi kondisi budaya, sosial, politik dan ekonomi. Kebutuhan akan mekanisme adaptasi tersebut 
dapat menjelaskan dampak dari adanya suatu perubahan atau pembangunan yang terjadi. Penjelasan tersebut diperlukan untuk mencegah terjadinya kesenjangan yang terjadi dari adanya perubahan atau pembangunan.

Oleh sebab itu, ke depannya desain politik hukum pengampunan pajak dalam perspektif Law and Development perlu memiliki prasyarat instrumen antisipasi terhadap kebijakan, hierarki peraturan yang jelas, mekanisme pengawasan dan penegakan hukum dan metode adaptasi terhadap kondisi sosial, politik dan ekonomi.

\section{b. Kepatuhan terhadap Peraturan}

Aspek kepatuhan terhadap peraturan dari mekanisme dampak peraturan dalam Teori Law and Development, mensyaratkan adanya pemahaman kuat terhadap nilainilai budaya dan pengetahuan umum. Ketaatan masyarakat terhadap sebuah peraturan sangat ditentukan oleh prasyarat tersebut. Kepatuhan masyarakat dalam membayar pajak bisa jadi sangat ditentukan oleh faktorfaktor budaya dan pengetahuan umum.

Misalnya, nilai-nilai budaya yang melekat atau dimiliki oleh masyarakat adalah sebuah masyarakat yang sangat menjunjung tinggi nilai keteladanan. Bisa jadi rendahnya kepatuhan masyarakat dalam membayar pajak karena dipengaruhi oleh faktor tersebut. Tidak adanya keteladanan dari para pemimpin kepala negara, kepala lembaga negara, menteri, kepala daerah hingga elit politik lainnya, dapat menyebabkan rendahnya kepatuhan terhadap peraturan.

Begitupun dengan hadirnya kebijakan program pengampunan pajak, kepatuhan masyarakat dalam mengikuti program tersebut sangat ditentukan oleh pengetahuan yang dimiliki masyarakat. Jika masyarakat tidak diberikan 
pengetahuan yang maksimal tentang program pengampunan pajak, maka secara otomatis masyarakat juga tidak akan mengerti apa itu program pengampunan pajak dan akhirnya juga tidak mengikuti program tersebut.

Jadi, kepatuhan terhadap sebuah peraturan, sangat ditentukan oleh faktor-faktor tersebut. Pemerintah dan seluruh stakeholder lainya patut memberikan penanaman nilai dan pengetahuan yang menyeluruh kepada masyarakat agar program pengampunan pajak ke depannya dapat berjalan lebih baik lagi. Jadi ke depannya, jika politik hukum pengampunan pajak akan kembali diterapkan, mesti lebih massive lagi perihal internalisasi nilai dan peningkatan pemberian pemahaman terkait dengan program pengampunan pajak secara komprehensif dan berkelanjutan.

c. Kualitas Pelaksanaan Perihal aspek kualitas pelaksanaan pada Teori Law and Development di bagian mekanisme dampak peraturan, sangat ditentukan oleh prasyarat kemampuan negara dan kemauan politik. Politik hukum pengampunan pajak ke depannya, yang paling penting disiapkan adalah prasyarat kemampunan negara dalam menghadapi tantangan yang akan hadir, baik dari dalam maupun datang dari luar negeri. Kebijakan program pengampunan pajak 2016 lalu, sangat terlihat bahwa negara tak mampu menghadapi tantangan yang datang dari luar, gangguan dari salah satu negara tax heaven. Negara seakan lumpuh tak berdaya menghadapinya, padahal di negara tersebut, terdapat banyak wajib pajak yang menyimpan dana beserta asetnya. Kenyataan tersebut sungguh ironi. Prasyarat lain yang juga menentukan adalah kemauan politik.

Pada aspek ini sebenarnya tinggal perlu lebih ditingkatkan lagi. 
Program pengampunan pajak 2016 yang lalu, terlihat jelas besarnya kemauan politik yang ditunjukkan oleh presiden sebagai kepala pemerintahan. Presiden bahkan turut serta melakukan sosialisasi ke berbagai daerah. Itu menunjukkan bahwa presiden sangat berkepentingan dalam menyukseskan program tersebut.

Kedepannya, politik hukum pengampunan pajak agar lebih mempersiapkan lagi perihal kekuatan pertahanan diri, kemampuan lebih kuat dalam menghadapi setiap tantangan yang ada, baik dari dalam maupun yang datang dari luar. Persoalan kemauan politik, agar lebih maksimal, setidaknya Presiden dan jajarannya serta para wakil rakyat lebih turut aktif dan turut serta dalam memberikan pemahaman dan melakukan sosialisasi kepada masyarakat. Dengan begitu, terlihatlah nyata political will dari para elit politik untuk membangun negara.
Jika pemerintah ingin kembali menerapkan kebijakan program pengampunan pajak, seyogianya menggunakan parameter dari perspektif Law and Development. Parameter tersebut sangat relevan dengan output yang ingin dicapai, sehingga keberadaannya sangat urgent. Keunggulan dari parameter tersebut ialah adanya fondasi parameter disiplin dan mekanisme dampak peraturan. Fondasi parameter disiplin dari perspektif Law and Development tersebut sangat penting dalam hal memetakan atau mengidentifikasi ruang lingkup dari suatu kebijakan.

\section{Penutup}

Berdasarkan uraian dari hasil penelitian dan analisis pembahasan yang telah dipaparkan dalam bab sebelumnya, berikut kesimpulan yang merupakan jawaban terhadap permasalahan penelitian, yaitu: politik hukum pengampunan pajak dalam kaitannya dengan Teori Law and Development masih belum optimal. Hal tersebut didasarkan pada parameterparameter dari Teori Law and Development 
dengan meninjau hasil capaian kebijakan pengampunan pajak. Pada aspek parameter disiplin maupun mekanisme dampak peraturan, politik hukum pengampunan pajak yang dibuat pemerintah mengesampingkan desain peraturan atau kaidah pembentukan peraturan perundang-undangan yang benar. Adapun kaidah pembentukan peraturan perundang-undangan yang dikesampingkan misalnya terlihat dari kebijakan yang dibuat kejar tayang atau tergesa-gesa, landasan filosofis dan sosioligis yang kurang jelas, pembahasan yang tertutup serta. Akibatnya, kebijakan pengampunan pajak tidak memiliki prioritas orientasi tujuan yang akan dicapai. Ketidakjelasan orientasi menyebabkan fokus perhatian menjadi tidak terarah dan hasilnya tidak optimal.

Politik hukum pengampunan pajak jika dikaitkan dengan perspektif Law and Development pada masa akan datang adalah seharusnya pemangku kebijakan melakukan perencanaan terlebih dahulu, menyusun desain kebijakan dengan baik, serta menyiapkan segala infrastruktur yang dibutuhkan. Hal tersebut penting guna dilakukannya pembahasan secara mendalam untuk memastikan bahwa proses pembentukan politik hukum pengampunan pajak dilakukan dengan benar berdasarkan parameter Law and Development. Menyusun desain peraturan dan menyiapkan segala infrastruktur pendukung, baik dalam hal peraturan pelaksana, kesiapan secara kelembagaan serta integritas aparaturnya. Hal tersebut penting karena dalam desain peraturan tercakup mekanisme analisis antisipasi terhadap hasil kebijakan. Keberadaan infrastruktur seperti kesiapan lembaga dan sikap profesional aparatur akan menjadi modal kuat dalam meningkatkan kepercayaan masyarakat. Di sisi yang lain, seluruh pihak wajib terlibat aktif dalam menyukseskan dan mengawal kebijakan program pengampunan pajak, baik itu dari kalangan pemerintah, pengusaha, maupun segala lapisan masyarakat.

Berdasarkan kesimpulan di atas, maka yang dapat penulis berikan sebagai rekomendasi, antara lain: perlunya dilakukan pembahasan dan kajian yang utuh dan mendalam, menyiapkan infrastruktur kelembagaan, melakukan pembinaan guna meningkatkan kapasitas dan profesionalitas aparatur, sehingga kebijakan program pengampunan pajak ke depannya terlaksana dengan optimal. 
Selanjutnya perlunya dibentuk suatu tim khusus untuk memastikan bahwa kebijakan pengampunan pajak telah sesuai dengan parameter Law and Development. Tim khusus tersebut berperan untuk membuat perencanaan, menyusun desain kebijakan, melakukan pengawasan dan evaluasi terhadap kebijakan, sehingga upaya menyusun kebijakan pengampunan pajak telah berdasarkan pada parameter Law and Development 


\section{DAFTAR PUSTAKA}

\section{A. Buku}

B.Ilyas, Wirawan dan Richard Burton, 2010, Hukum Pajak, Salemba Empat, Jakarta.

Mahmud Marzuki, Peter 2010, Penelitian Hukum, Kencana, Jakarta.

Prastowo, Yustinus, 2017, Pengampu(n)an Pajak Historiografi Perjalanan Amnesti Pajak di Indonesia, CITA Riset Fiskal, Jakarta.

Rosdiana, Haula dan Edi Slamet Irianto, 2012, Pengantar Ilmu Pajak: Kebijakan dan Implementasi di Indonesia, Rajawali Pers, Jakarta.

Shidarta, et al, 2012, Mochtar Kusuma-Atmadja dan Teori Hukum Pembangunan, Epistema Institue, Jakarta.

Soekanto, Soerjono, 1984, Pengantar Penelitian Hukum, UI Press, Jakarta.

Sumardjono, Maria S.W, 2014, Metodologi Penelitian Ilmu Hukum, UGM,

Yogyakarta.

\section{B. Peraturan Perundang-Undangan}

Putusan Mahkamah Konstitusi Nomor 57/PUU-XIV/2016 perihal Pengujian UndangUndang Nomor 11 Tahun 2016 tentang Pengampunan Pajak

\section{Risalah Sidang}

Rapat Kerja Komisi XI DPR RI, Mendapatkan Masukan terkait Pembahasan RUU tentang Pengampunan Pajak, Rabu, 20 April 2016

\section{Jurnal dan Hasil Penelitian}

Saka Winih W, 2016, Analisis Faktor yang Mempengaruhi Efektivitas Kebijakan Pengampunan Pajak, Program Studi Sarjana Akuntansi Fakultas Ekonomika dan Bisnis Universitas Gadjah Mada, Skripsi, Yogyakarta

Yong Shik Lee, General Theory of Law and Development, Cornell International Law Journal, Vol. 50. No. 3 Desember 2017, United Stated.

\section{E. Surat Kabar dan Majalah}

Majalah Gatra, Skenario Lanjutan Pasca Program Pengampun Pajak Berakhir, Edisi 6 - 12 April 2017.

Majalah Tempo, Melempem Di Babak Akhir, Edisi 10-16 April 2017.

Yustinus Prastowo, Pasca-program Amnesti Pajak, Kompas, 5 April 2017 


\section{F. Internet}

"Panama Papers, Jejak Korupsi Global dari Panama", https://investigasi.tempo.co/panama/

http://www.hukumonline.com/berita/baca/lt58343e35f2fc3/pejabat-pajak-tersangka suap-rp1-9-m-saat-pemerintah-gencarkan-tax-amnesty, 


\section{BIODATA PENULIS}

Akmaluddin Rachim, S.H., M.H. lahir di Sinjai, Menyelesaikan pendidikan pada S1 Ilmu Hukum di Universitas Muhammadiyah Malang dan S2 Magister Hukum di Universitas Gadjah Mada, Yogyakarta. Saat ini penulis terlibat aktif dalam lembaga penelitian di Jakarta. Penulis dapat dihubungi melalui email: adinrach91@gmail.com 